\title{
POLA ASUH DEMOKRATIS ORANG TUA DALAM PENGEMBANGAN POTENSI DIRI DAN KARAKTER ANAK USIA DINI
}

\author{
Adpriyadi $^{1}$ \& Sudarto $^{2}$ \\ ${ }^{1,2}$ PG-PAUD, STKIP Persada Khatulistiwa Sintang
}

Email: adpriyadi@gmail.com, sudarto.niarto@gmail.com

INFO ARTIKEL
$\begin{aligned} & \text { Riwayat Artikel: } \\ & \text { Menerima }\end{aligned}$
$\begin{array}{ll}\text { Revisi } & : 14 \text { Desember } 2019 \\ \text { Diterima } & : 23 \text { April } 2020 \\ \end{array}$

\section{Kata Kunci:}

Pola Asuh, Potensi Diri, Karakter

\section{Keywords:}

Parenting, Self Potential, Character

\section{Korespondensi:}

Adpriyadi

PG-PAUD STKIP Persada

Khatulistiwa, Sintang

Email : adpriyadi@gmail.com

\section{ABSTRAK}

Pendidikan yang utama dan pertama didapat anak dari orang tua. Orang tua memiliki peran penting dalam hal ini sebab orang tua adalah teladan pertama yang dikenal oleh anak. Peran orangtua yang demokratis menerapkan orang tua yang menjadikan anak-anak menjadi orang yang mau menerima kritik dan menghargai orang lain, memiliki kepercayaan diri yang tinggi dan mampu bertanggung jawab atas kehidupan sosial mereka. Permasalahan yang diangkat dalam penelitian ini adalah bagaimana pola asuh orang tua dalam pengembangan diri dan karakter anak usia dini. Penelitian ini bertujuan untuk mengetahui peran orang tua dalam penggembangan potensi dan karakter anak usia dini dengan pola asuh demokratis. Penelitian ini dianalisis dengan menggunakan metode kualitatif deskriptif. Teknik pengumpulan data menggunakan wawancara, observasi dan dokumentasi. Hasil penelitian menunjukan metode yang diterapkan orang tua dalam penggembangan potensi diri dan karakter anak antara lain: a) memberikan pujian dan penghargaan kepada anak, b) menyediakan waktu bermain bersama anak, c) memberikan kasih sayang dan perhatian, d) memberikan keteladanan yang baik.

\section{ABSTRACT}

First and foremost education is obtained by children from parents. Parents have an important role in this case because parents are the first examples known by children. The role of democratic parents applies parents who make their children willing to accept criticism and respect others, have high self-confidence and are able to take responsibility for their social lives. The problem raised in this study is how parenting parents in self-development and character of early childhood. This study aims to determine the role of parents in developing the potential and character of early childhood with democratic parenting. This research was analyzed using descriptive qualitative methods. Data collection techniques using interviews, observation and documentation. The results showed that the methods applied by parents in developing children's potential and character include: a) giving praise and appreciation to children, b) providing time to play with children, c) giving love and attention, d) giving good role models.

\section{PENDAHULUAN}

Keluarga merupakan kesatuan yang terkecil di dalam masyarakat tetapi menempati kedudukan yang sangat penting oleh sebab itu keluarga mempunyai peranan yang besar dalam mempengaruhi kehidupan seorang anak, terutama pada tahap awal maupun tahap-tahap kritisnya. Keluarga adalah sekelompok orang yang menyatu dalam ikatan pernikahan, sedarah atau adopsi, mendirikan suatu rumah tangga, melakukan interaksi dan komunikasi berkelanjutan dalam respektif pada aturan sosial dari suami dan istri, ibu dan ayah, anak laki-laki dan anak perempuan, saudara laki-laki dan saudara perempuan, menghasilkan dan memelihara suatu budaya umum. Artinya 
bahwa Keluarga merupakan unit terkecil dalam masyarakat yang terbentuk akibat adanya perkawinan berdasarkan agama dan hukum yang sah. Pengaruh dari keluarga sangat penting karena keluarga merupakan awal pembelajaran bagi seoranganak.

\section{Dorongan dari keluarga kepada} anaknya salah satunya adalah dengan memberikan pendidikan yang terbaik sejak dini (Masni 2017: 59). Pendidikan merupakan salah satu cara meningkatkan potensi manusia untuk bangkit dari dunia kebodohan. Di era global seperti ini individu tidak akan mencapai kehidupannya secara maksimal dan puas tanpa adanya pendidikan. Pendidikan Pendidikan Anak Usia Dini (PAUD) adalah jenjang paling dasar pada pendidikan formal di Indonesia. Sekolah Dasar ditempuh dalam waktu 6 tahun, mulai dari kelas 1 sampai kelas 6. Pelajar sekolah dasar umumnya berusia 7-12 tahun. Dalam perspektif pendidikan, terdapat tiga lembaga utama yang sangat berpengaruh dalam perkembangan kepribadian seorang anak yaitu lingkungan keluarga, lingkungan sekolah dan lingkungan masyarakat, yang selanjutnya dikenal dengan istilah Tripusat Pendidikan.

$$
\text { Keluarga memberikan dasar }
$$
pembentukan tingkah laku, watak, moral, dan pendidikan anak. Mengasuh dan membesarkan anak berarti memelihara kehidupan, kesehatan, mendidik dengan penuh ketulusan dan cinta kasih. Dalam membimbing anak, orangtua tidak hanya memenuhi kebutuhan psikis saja namun dituntut pula untuk dapat memenuhi kebutuhannya secara financial (Masni 2017: 59) . Salah satu masalah orang tua bekerja atau berkarir adalah menentukan pola bimbingan bagi anak yang membuat anak merasa aman, nyaman, terlindungi, perhatian dan tercukupi segala kebutuhannya (sandang, pangan,dan papan). Dilematis bagi orangtua yang memilih antara memenuhi kebutuhan secara psikis dan fisik, karena keduakebutuhan tersebutharuslah seimbang dan dapat dimiliki oleh anak. Jika orangtua sibuk bekerja maka itensitas perhatian pada keluarga menjadi berkurang, namun jika orangtua tidak bekerja maka ekonomi keluarga menjadi terganggu atau kurang tercukupi. Dua kondisi ini bukanlah untuk dijadikan alasan orangtua untuk menghindar dari tanggung jawab jika salah satu kebutuhan tersebut tidak dapat terpenuhi. Orangtua harus memberikan rasa cinta, kasih sayang, kenyamanan, ketentraman dan kesejahteraan dalam keluarga.

Anak Usia PAUD ini, dituntut untuk menjalankan tugas perkembangannya sesuai dengan tingkat perkembangannya, agar tidak mengalami kesulitan dalam menghadapi tugas perkembangan berikutnya. Untuk membantu siswa menempuh tugas-tugas perkembangannya, Pendidikan Anak Usia Dini ( PAUD)ditetapkan sebagai wadah bagi anak untuk mengembangkan diri. Dalam Undangundang No.20 tahun 2003 Pasal 3 menyatakan bahwa Pendidikan nasional berfungsi mengembangkan kemampuan dan membentuk watak serta peradaban bangsa yang bermartabat dalam rangka mencerdaskan kehidupan bangsa. Tujuan dari undang-undang diatas bahwa untuk dapat berkembangnya potensi siswa agar menjadi manusia yang beriman dan bertaqwa kepada Tuhan Yang Maha Esa, berakhlak 
mulia, sehat, berilmu, cakap, kreatif, mandiri, dan menjadi warga negara yang demokratis serta bertanggung jawab. Pendidikan merupakan usaha sadar untuk menyiapkan peserta didik melalui kegiatan bimbingan, pengajaran dan latihan bagi peranannya dimasa datang. Namun untuk mencapai tujuan tersebut tidak hanya bertumpu pada pendidikan formal, tetapi juga lingkungan keluarga danmasyarakat.Uraian di atas menunjukkan bahwa orang tua dituntut untuk mampu mengasuh dan mendidik anaknya agar menjadi manusia utuh, baik dari segi fisik, maupun perkembangan kepribadian dan intelektualnya. Lebih lanjut, Dreikust (dalam Balson, 2003:1) menjelaskan keprihatinannya terhadap perlakuan yang salah, menurutnya alasan yang paling menonjol dalam berkurangnya kebiasaan dalam mengurus anak. Para orang tua saat ini tidak mengetahui apa yang harus dilakukan terhadap anaknya. Sementara itu Carpenter (2001:115) menguraikan akibat yang ditimbulkan perlakuan yang salah dalam mendidik anak. Misalnya: Kasih sayang yang berlebihan sehingga anak menjadi tergantung (over protected), pengawasan kurang tetapi kasih sayang berlebihan anak akan menjadi manja (spolled), pengawasan dan disiplin yang berlebihan tetapi kurang kasih sayang anak menjadi ditolak (projected), apabila pengawasan maupun kasih sayangnya sedikit maka akanmerasadilalaikan (neglected). Berdasarkan pendapat ahli ini, maka untuk melihat sejauh mana perlakuan dan peranan orang tua dalam gaya pengasuhannya berupa kontrol terhadap perilaku dan nilai kehidupan yang mampu mempengaruhi sikap dan tingkahlaku anak-anaknya dimasa depan.

Pada umunya sebagian orang enggan untuk memikirkan suatu perubahan, mereka berpikir bahwa sudah ada orang yang berwenang, pintar yang telah ditugaskan. Pola pikir yang tidak baik ini dipelihara oleh orang yang tidak mau berpikir. Orang bersikap tidak berdaya, berdiam diri, protes, menggantungkan harapan datangnya inspirasi cerdas dari orang pintar dan para pemimpin. Masalah yang dihadapi seharusnya mendorong banyak ide, gagasan, dan solusi kreatif (Rachman dan Savitri, 2011). Kesejahteraan dan kejayaan masyarakat dan negara tergantung pada sumbangan kreatif berupa ide-ide, penemuan dan teknologi baru dari masyarakatnya (Heller dalam Suharnan, 2000).

Kreativitas tidak datang dengan sendirinya, namun perlu dikembangkan sejak dini (Icai, 2011). Potensi kreatif seorang anak akan aktual dalam bentuk perilaku, karena adanya rasa aman dan bebas (Hurlock dalam Munandar, 1999). Kebutuhan rasa aman yang diperlukan dalam tumbuh kembang kreativitas remaja akan terpenuhi dalam lingkungan keluarga berpola asuh demokratis (Mappiare, 1982). Dibanding keluarga biasa, dalam keluarga remaja kreatif tidak banyak aturan yang diberlakukan (Dacey dalam Munandar,1999).

Pendapat diatas mempertegas bahwa untuk menjadi orang kreatif dibutuhkan kecerdasan, namun kecerdasan tidak akan berkembang dengan baik tanpa ada faktor pendukung lainnya. Dengan kata lain bahwa 
orang cerdas belum tentu kreatif, tetapi orang yang kreatif sudah pasti cerdas. Artinya bahwa banyak orang yang cerdas namun tidak mampu berinovasi, hanya orang yang cerdas kreatiflah yang bisa berinovasi, dan hal ini dapat terjadi karena adanya berbagai faktor pendukungnya seperti keluarga, sekolah, lingkungan dan teknologi.

Fenomena diatas menjadi keprihatinan bagi diri peneliti, karenanya peneliti berkeinginan untuk mengkaji secara mendalam. Langkah awal yang peneliti lakukan adalah mewawancarai keluarga dengan kelompok pola asuh yang berbeda dan disesuaikan dengan tipe pola asuh yang mereka terapkan kepada anak-anaknya serta dampaknya terhadap pengembangan potensi anaknya.Hasil sementara Dari 6 orang yang diwawancarai dengan 3 kelompok keluarga (keluarga dengan pola demokrasi,otoriter dan permisif dengan hasil optimalisasi pengembangan potensi anaknya, yang juga peneliti kelompokkan menjadi dua kelompok yaitu kelompok anak-anak yang potensinya berkembang optimal dengan anak-anak yang kurang ataubelum berkembangan potensi dirinya), hasil sementara 3 dari 6 orangtua mengatakanmendidik anaknya sangat disiplin, anak harus mengikuti kemauan dan aturan yang ditetapkan orang tua (authoritarian), 4 dari 6 ibu mengatakan menerapkan disiplin pada anak sesuai dengan kemampuannya, mengikuti kemauan anak namun tetap diarahkan (demokratif), 4 dari 6 ibu memberikan kebebasan kepada anaknya untuk menentukan perilaku yang diinginkannya, tidak menerapkan disiplin khusus pada anaknya (permissive).

Secara eksplisit gambaran umum diatas merupakan kesenjangan akan gaya pengasuhan orangtua dalam keluarganya, termasuk dalam memenuhi kebutuhan baik secara fisik maupun psikis serta harapan- harapan ataupun keinginan orangtua terhadap anak-anaknya. Paparan diatas menjadi alasan bagi penulis untuk membahas fenomena tersebut. Gambaran akan fenomena yang dialami oleh orangtua, khususnya tentang peranan gaya pengasuhan atau pola asuh orang tua yang sangat mempengaruhi keberhasilan anak-anaknya dimasa depan, tidak hanya sukses dalam kehidupan dunia namun juga kehidupan akhirat serta menghantarkan anak-anak menjadi manusia yang memiliki harkat dan martabat di sisi manusia dan memiliki kemuliaan disisi SangPenciptanya.

Menyikapi fenomena global ini, maka penanaman nilai pendidikan awal berasal dari keluarga sebagai pondasi anak mengenal pendidikan awal khusunya dalam beradaptasi dan penanaman nilai keagamaan ke dalam jiwa anak. Keluarga pada masa pembangunan (dalam konteks ke-Indonesiaan dikenal dengan era tinggal landas) tetap diharapkan sebagai lembaga sosial yang paling dasar untuk mewujudkan pembangunan kualitas manusia dan lembaga ketahanan untuk mewujudkan manusia yang bermoral. keluarga merupakan titik awal dan sebagai modal perjalanan hidup sesorang. Mengingat pentingnya strategis dari makna fungsional keluarga, maka peneliti termotivasi untuk mengangkat masalah ini 
untuk selanjutnya disuguhkan dalam bentuk jurnal "Peran Pola Asuh Demokratis Orangtua Terhadap Pengembangan Potensi Diri dan kreativitas Siswa".

Uraian latar belakang di atas menjadikan fokus masalah jurnal ini adala maka Bagaimanakah peran pola asuh demokratis orangtua dapat mengembangkan potensi diri siswa. Dengan tujuan bahwa untuk dapat mengetahui peran pola asuh demokratis orangtua dalam mengembangkan potensi diri siswa. Dan jurnal ini juga akanbermanfaat baik Secara Teoritis sebagai sumbangsi terhadap dunia pendidikan dan bermanfaat Secara Praktis baik bagi sekolah, orangtua, guru, siswa dan peneliti sendiri.

\section{HASIL DAN PEMBAHASAN}

\section{Pola Asuh Orang Tua}

Pola bimbingan atau pola asuh orangtua pada umumnya sangat mempengaruhi kepribadian seorang anak. Pola bimbingan orangtua dalam mendidik anak dapat terlihat pada kemandirian, mengenali dan memahami dirinya, mampu membuat pilihan dan dapat merencanakan masa depannya. Jadi Hal-hal yang perlu dilakukan orang tua dalam membimbing anaknya adalah membantu anakanak memahami posisi dan peranannya sesuai dengan jenis kelaminya, agar mampu saling menghormati dan saling tolong-menolong dalam melaksanakan perbuatan yang baik, Membantu anak-anak mengenal dan memahami nilai-nilai yang mengatur kehidupan berkeluarga, bertetangga, bermasyarakat, dan mampu melaksanakannya sesuai dengan norma yang berlaku, Mendorong anak-anak untuk mencari ilmu dunia dan ilmu agama, agar mampu merealisasikan dirinya sebagai individu dan bagian dari masyarakat, Membantu anak-anak memasuki kehidupan bermasyarakat setahap demi setahap melepaskan diri dari ketergantungan pada orang tua dan orang dewasa lainnya, serta mampu bertanggung jawab atas sikap dan perilakunya, serta Membantu dan memberi kesempatan serta mendorong anak-anak mengerjakan sendiri dan berpartisipasi dalam melaksanakan kegiatan agama, didalam keluarga danmasyarakat.

Pola asuh orangtua dalam keluarga Menurut Syaiful (2014:50) merupakan frase yang menghimpun empat unsur penting yaitu pola,asuh,orangtua,keluarga. Kamus Besar Bahasa Indonesia Pola berarti corak,model, sistem,cara kerja, bentuk (struktur)yang tetap. Artinya disini bahwa ketika pola atau bentuk atau struktur yang diberikan menjadi tetap atau permanen maka hal ini akan menjadi sebuah kebiasaan. Asuh (KBBI 2000: 21) artinya mengasuh, yang bermakna (1) menjaga (merawat dan menjaga) anak kecil, (2) membimbing (membantu, melatih) supaya dapat berdiri sendiri, (3) memimpin (mengepalai, menyelenggarakan) suatu badan kelembagaan. Makna dari asuh tersebut, bahwa ketika ada sebutan pengasuh yang berarti orang yang mengasuh (orangtua, wali dan sejenisnya) sedangkan ketika ada kata pengasuhan berarti proses perbuatan, dan cara pengasuhan. Jadi dapat disimpulkan bahwa kata asuh mencakup segala aspek yang berkaitan dengan pemiliharaan,perawatan, dukungan, dan 
bantuan sehingga orang tetap berdiri dan menjalani hidupnya secarasehat.Kata orangtua (KBBI 2001:121) adalah ayah-ibu kandung (orangtua) orang yang dianggap tua (cerdik pandai,ahli dan sejenisnya), orang yang dihormati (disegani) di kampung. Artinya dalam konteks keluarga, orangtua bermakna ayah ibu kandung dengan tugas tanggung jawab mendidik anak dalam keluarga.Jadipola asuh orangtua dalam keluarga berarti kebiasaan orangtua, ayah- ibu dalam memimpin, mengasuh dan membimbing anak dalam keluarga. Mengasuh dalam arti menjaga dengan cara merawat dan mendidiknya, dan membimbing dengan cara membantu, melatih dan lain sebagainya.

Berdasarkan pendapat diatas dapat disimpulkan bahwa Pola membimbing bermakna pendidikan, sedangkan pendidikan adalah bimbingan secara sadar oleh pendidik terhadap perkembangan jasmani dan rohani anak didik menuju terbentuknya kepribadian yang utama. Jadi pola asuh orang tua adalah suatu keseluruhan interaksi antara orang tua dengan anak, di mana orang tua bermaksud menstimulasi anaknya dengan mengubah tingkah laku, pengetahuan serta nilai-nilai yang dianggap paling tepat oleh orang tua, agar anak dapat mandiri, tumbuh dan berkembang secara sehat dan optimal.

Pola asuh orangtua merupakan pola perilaku yang diterapkan pada anak dan besifat relatif konsisten. Pola perilaku ini dapat dirasakan oleh anak dan bisa memberikan efek negatif maupun positif. Menurut Koentjaraningrat (dalam Syaiful 2014:53) pola asuh yang diterapkan orangtua sangat dominan dalam membentuk kepribadian anak sejak kecil hingga dewasa, dan pola suh yang diterapkan suatu suku bangsa akan melahirkan anak dengan kepribadian yang khas. Orangtua memiliki cara tersendiri dalam mengasuh dan membimbing anaknya setiap keluarga memiliki cara dan pola yang berbeda antara keluarga yang satu dengan yang lainnya. Pola asuh orangtua merupakan gambaran perilaku orangtua dan anak dalam berinteraksi, memberikan perhatian, peraturan, kedisiplinan, reward dan funismant, serta tanggapan terhadap keinginan anaknya. Sikap, perilaku dan kebiasaan orangtua selalu memiliki nilai dan akan ditiru oleh anaknya secara terus menerus dan akan menjadi kebiasaan bagi anak-anaknya.

\section{Model-model Pola asuh Orangtua}

Ada beberapa macam model pola kepemimpinan dalam konteks tipe pola asuh dalam keluarga yaitu model pola kepemimpinan, pemimpin dan pengikut, kepemimpinan $\mathrm{Ki}$ Hajar Dewantara dan Kepemimpinan Pancasila. Selain itu pola asuh orangtua memiliki beberapa tipe yaitu Gaya Otoriter/Autokratis, Demokratis, Asuh Permisif, Asuh Laissez Faire, Fathernalistik, Karismatik, Melebur Diri, Pelopor, Manipulasi, Transaksi, Biar Lambat Asal Selamat, Alih Peran, Pamrih, Konsultasi, dan Militeristik.(Widjaja dalam Syaiful 2014:56).

Ke tiga model pola asuh dengan ke beberapa tipe atau gaya pengasuhan yang dipaparkan teori diatas merupakan bentuk pola asuh yang ada di Indonesia, bahkan tidak 
menutup kemungkinan bahwa diantara tipe pola asuh diatas juga digunakan oleh negara lain sepertidi negara Jepang dengan tingkat kedisiplinan yang sangat baik dan di negara Amerika yang menerapkan setiap warganya memiliki kewajiban untuk mengikuti pendidikan militer. Hal ini dapat pahami bahwa tipe atau gaya militeristik yang lebih mendominasi oragtua dalam memberikan pengasuhan dan pendidikan dalam keluarganya.

Berbagai model dengan tipe pola asuh diatas dapat digunakan oleh orangtua dalam memberikan pengasuhan pada anak-anaknya. Berbagai macam jenis pola asuh diatas akan ada kemungkinan dan bias orangtua melakukan kolaborasi ataupun variasi dalam mendidik anak-anaknya. Namun yang perlu diingat dan ditekankan disini bahwa apapun usah orantua untuk memberikan yang terbaik untuk keluarganya khususnya anak-anaknya harus tetap mengutamakan hak- hak anak sebagai manusia yang berharkat dan bermatabat sesuai dengan bakat minat kemampuan dan kebutuhananak.

Pembahasan jurnal ini difokuskan pada pola asuh demokratis. Pola asuh adalah cara, bentuk atau strategi dalam pendidikan keluarga yang dilakukan oleh orangtua kepada anaknya. Pola asuh demokratis adalah cara mendidik anak, di mana orang tua menentukan peraturanperaturan tetapi dengan memperhatikan keadaan dan kebutuhan anak Dengan demikian merupakan suatu hak dan kewajiban orangtua sebagai penanggung jawab yang utama dalam mendidik anaknya (Shochib, 2010). Sedangkan
Hurlock (2004) berpendapat bahwa pola asuh demokratis menekankan kepada aspek edukatif atau pendidikan dalam membimbing anak sehingga orangtua lebih sering memberikan pengertian, penjelasan, dan penalaran untuk membantu anak mengerti mengapa perilaku tersebut diharapkan.

Pola pengasuhan orangtua ada banyak macamnya seperti pola asuh demokratif. Menurut Waruan (Utami, 2009) aspek pola asuh demokratis orangtua yaitu kasih sayang, komunikasi, kontrol, tuntutan kedewasaan. Sedangkan factor-faktor yang mempengaruhi pola asuh demokratis menurut Watson (Windyastati, 2001) yaitu faktor nilai yang dianut oleh orangtua, faktor kepribadian, factor sosial ekonomi, dan tingkat pendidikan. Sedangkan Syaiful (2014:61) berpendapat pola asuh demokratis adalah tipe pola asuh yang terbaik dari tipe pola asuh yang lainnya. Pola asuh demokratis merupakan suatu bentuk pola asuh yang memperhatikan dan menghargai kebebasan anak, namun kebebasan itu tidak mutlak dan dengan bimbingan yang penuh pengertian antara orang tua dan anak. Dengan kata lain, pola asuh demokratis ini memberikan kebebasan kepada anak untuk mengemukakan pendapat, melakukan apayang diinginkannya dengan tidak melewati batas-batas atau aturan yang telah ditetapkan orang tua. Orang tua juga selalu memberikan bimbingan dan arahan dengan penuh pengertian terhadap anak Karenanya orangtua selalu mendahulukan kepentingan anak dan tidak banyakdalammenggunakan kontrol terhadap 
anak. Sehingga pola ini bisa digunakan untuk anak SD,SMP,SMA dan PerguruanTinggi.

Pola asuhan demokratif ditandai dengan adanya sikap terbuka antara orang tua dengan anaknya. Mereka membuat aturanaturan yang disetujui bersama. Anak diberi kebebasan untuk mengemukakan pendapat, perasaan dan keinginanya dan belajar untuk dapat menanggapi pendapat orang lain. Orang tua bersikap sebagai pemberi pendapat dan pertimbangan terhadap aktivitas anak. Dengan pola asuhan ini, anak akanmampu mengembangkan kontrol terhadap prilakunya sendiri dengan hal-hal yang dapat diterima oleh masyarakat. Hal ini mendorong anak untuk mampu berdiri sendiri, bertanggung jawab dan yakin terhadap diri sendiri. Daya kreativitasnya berkembang baik karena orang tua selalu merangsang anaknya untuk mampu berinisiatif. Anak yang dibesarkan dalam keluarga yang bersuasana demokratik, perkembangannya lebih luwes dan dapat menerima kekuasaan secara rasional. Sebaliknya anak yang dibesarkan dalam suasana otoriter, memandang kekuasan sebagai sesuatu yang harus ditakuti dan bersifat rahasia. Ini mungkin menimbulkan sikap tunduk secara membuta kepada kekuasaan, atau justru sikap menentang kekuasaan. Tipe demokratis mengharapkan anak untuk berbagi tanggung jawab dan mampu mengembangkan potensi kepemimpinan yang dimilikinya. Adapun ciri-ciri pola asuh demokratis menurut Syaiful (2014:61) adalah sebagaiberikut:

1) Proses pendidikan terhadap anak selalu bertitik tolak dari pendapat bahwa manusia adalah makhluk mulia didunia.

2) Orangtua selalu menyelaraskan kepentingan dan tujuan pribadi dengan kepentingan kepentingananak

3) Orangtua senang menerima pendapat, saran dan kritikan darianak

4) Mentolerir ketika anak membuat kesalahan dan memberikan pendidikan kepada anak agar jangan melakukan kesalahan lagi tanpa mengurangi daya kreativitas, inisiatif dan prakarsa darianak

5) Lebih menitik beratkan kerja sama dalam mencapaitujuan

6) Orangtua selalu berusaha untuk menjadikan anak lebih sukses darinya.

Pola asuh demokratis, membuat anak akan menjadi orang yang mau menerima kritik,menghargai orang lain, mempunyai kepercayaan diri yang tinggi dan mampu bertanggung jawab terhadap kehidupan sosialnya. Tidak ada orang tua yang menerapkan salah satu macam pola asuh dengan murni, dalam mendidik anak-anaknya. Orang tua menerapkan berbagai macam pola asuh dengan memiliki kecenderungan kepada salah satu pola yang dominan cocok dalam keluarganya.

\section{Pengembangan Potensi Diri Siswa}

Kata potensi berasal dari serapan dari bahasa Inggris, yaitu potencial. Artinya ada dua kata yaitu (1) kesanggupan; tenaga (2) kekuatan;kemungkinan. Sedangkan menurut kamus besar bahasa Indonesia, definisi potensi adalah kemampuan yang mempunyai kemungkinan untuk dikembangkan, kekuatan, 
kesanggupan, daya. Intinya, secara sederhana, potensi adalah sesuatu yang bisa kita kembangkan (Majdi, 2007:86). Potensi dapat diartikan sebagai kemampuan dasar dari sesuatu yang masih terpendam didalamnya yang menunggu untuk diwujudkan menjadi sesuatu kekuatan nyata dalam diri sesuatu tersebut (Wiyono,2006:37). Artinya potensi diri manusia adalah kemampuan dasar yang dimiliki manusia yang masih terpendam didalam dirinya yang menunggu untuk diwujudkan menjadi suatu manfaat nyata dalam kehidupan dirimanusia.

Menurut Endra K Pihadhi (2004:6) potensi bisa sebagai kekuatan, energy atau kemampuan yang terpendam,dimiliki dan belum dimanfaatkan secara optimal. Potensi diri yang dimaksud disini suatu kekuatan yang masih terpendam

berupa

fisik,karakter,minat,bakat,kecerdasan dan nilainilai yang terkandung dalam diri tetapi belum dimanfaatkan dan diolah. Sedangkan Sri Habsari (2005:2) menjelaskan, potensi diri adalah kemampuan dan kekuatan yang dimiliki oleh seseorang baik fisik maupun mental dan mempunyai kemungkinan untuk dikembangkan bila dilatih dan ditunjang dengan sarana yang baik. Sedangkan diri adalah seperangkat proses atau ciri-ciri proses fisik,perilaku dan psikologis yang dimiliki.Selanjutnya Buchori (dalam Suprapti dan Ratna 2001:3) bahwa potensi merupakan "daya". Daya tersebut dapat bersifat positif berupa kekuatan (power) dan bersifat negatif berupa kelemahan (weaknesses).
Dari pengertian diatas dapat disimpulkan bahwa potensi diri merupakan kemampuan dasar yang dimiliki oleh seseorang yang masih terpendam dan mempunyai kemungkinan untuk dapat dikembangkan jika didukung dengan peran serta lingkungan, latihan dan sarana yangmemadai.

\section{Pengenalan dan Pengukuran Potensi Diri}

Pengenalan berasal dari kata kenal atau tahu. Setiap manusia memiliki potensinya masing-masing dan berbeda antara satu dengan yang lainnya. Ada induvidu dengan rentang usia yang dewasa masih ada yang tidak mengetahui potensi dirinya. Bagaimana mungkin manusia dapat mengembangkan potensi dirinya, sedangkan Ia tidak mengenalinya. Salah satu cara untuk mengenalinya adalah dengan menggunakan pengukuran (measurement) yaitu kegiatanpengumpulan data dengan menggunakan alat ukur atau instrumen untuk mengetahui potensi yangdimiliki.

Manusia memiliki beragam potensi diantaranya Potensi Berfikir,Potensi Emosi, Potensi Fisik, dan Potensi Sosial (Nashori, 2003:89). Sedangkan menurut Suprapti dan Ratna (2001:4) beberapa contoh potensi yang dimiliki manusia antara lain kejujuran, ketegasan, kesucian, keimanan, kesetiaan, kerapian, kematangan, kedewasaan, kecerdikan, kebijakan, kecerdasan, kebenaran, keramahan dan sebagainya. Selanjutnya Hery Wibowo (2007:1) juga berpendapat bahwa minimal ada empat kategori potensi yang terdapat dalam diri manusia sejak lahir yaitu, potensi otak, emosi, fisik dan spiritual dan 
semua potensi ini dapat dikembangkan pada tingkat yang tidak terbatas. Ahli lain berpendapat bahwa manusia itu diciptakan dengan potensi diri terbaik dibandingkan dengan makhluk Tuhan yang lain, ada empat macam potensi yang dimiliki oleh manusia yaitu,potensi intelektual,emosional, spiritual danfisik.

\section{Hambatan Pengembangan Potensi Diri}

Potensi diri seseorang dapat berkembang tergantung pada induvidu dan lingkungan dimana dia berada. Hambatan potensi diri yang dominan adalah berasal dari induvidu dan lingkungan.Menurut Mike dalam Suprapti (2001:41) memberikan beberapa hal yang dapat menghambat pengembangan diri yaitu: 1)ketidakmampuan mengatur diri, 2) nilai pribadi yang tidak jelas, 3) tujuan pribadi yang tidak jelas,4) pribadi yang kerdil, 5)kemampuan yang tidak memadai untuk memecahkan masalah. 6)kreativitas rendah, 7) wibawa rendah, 8) kemampuan pemahaman manajerial rendah, 9) kemampuan menyelia rendah, 9) kemampuan latih rendah, 10) kemampuan membina tim rendah.

Konsep diri merupakan bagain yang cukup berpengaruh dalam pengembangan potensi diri seseorang. Konsep diri adalah cara seseorang memandang situasi disekelilingnya, tentang siapa saya, pikiran saya, dimana posisi saya berada dan apa yang boleh dan tidak dilakukan. Konsep diri tersebut mulai dilihat dari tingkat golongan yaitu 1)golongan yang menyerah total, 2) golongan tidak menyerah total, 3) golongan yang tidak mudah menyerah. Menurut Jhon Robert Power dalam program pengembangan probadi mengklasifikasikan konsep diri yaitu: 1)sebagai penonton (People who watch things happen), 2) sebagai obyek (people to whom things happen), 3) sebagai orang buta (people who don,t know what is happening).

Jadi dari pendapat diatas Jika ingin mengembangkan konsep diri maka golongan terakhir harus menjadi alternatif pilihan. Jika memilih menjadi pelaku yang berhasil the winner) maka bentuklah diri untuk memiliki self image positive. Sedangkan jika memilih menjadi kalah (Loser) maka bentuk diri seseorang itu memiliki citra diri negatif (self image negative)

\section{Rancangan Pengembangan Potensi diri}

Pengembangan potensi diri dan aktualisasi diri baru dapat dilakukan setelah kegiatan diatas dilaksanakan agar dapat berjalan dengan efektif. Untuk mengembangkan potensi diri bukan hanya aspek fisik tetapi juga memerlukan gizi. Menurut pendapat La Rose, (pada kegiatan citra pribadi yang berkualitas, Pustaka kartini 2002 dalam Suprapti) menyatakan bahwa gizi pengembangan potensi tersebut antaralain:

1) Bergaul dengan orang yang satu profesi untuk memperoleh peluang dan tantangan.

2) Pilih teman yang bisa diajak berdiskusi dan tidak mudah tersinggung serta mau menberikan umpan balik yang sesuai dengan realita.

3) Bersikap dan berpikir positif dengan sesama. 
4) Biasakan mengatakan hal-hal yang menghargai oranglain.

5) Bisakan bicaraefektif.

Untuk mendapatkan pengakuan orang lain maka setiap manusia harus mampu mengaktulisasikan dirinya dengan koreksi diri sendiri dan merenungi hakekat diri. Karenanya sebelum aktulisasi dilakukan maka diperlukan perencanaan atau desain dalam mengembangkan potensi diri yaitu:

1) Menentukan sasaran yangjelas

2) Menentukan cara menilai keberhasilan

3) Mensykuri kemajuan walaupun hanyasedikit.

4) Berani mengambilresiko

5) Perkembangan diatur oelh dirisendiri

6) Memanfaatkan setiap kesempatan yangada

7) Terbuka untuk belajar dengan siapasaja

8) Belajar darikesalahan

9) Jangan banyak bicara tapi kerjakan yangdiucapkan.

Rencana Pengembangan Potensi Diri: 1)Tentukan potensi yang akan dikembangkan (aspek pengetahuan, sikap atau keterampilan) 2)Tentukan sasaran yang akan dikembangkan, berapa batas waktu yang tersedia, faktor-faktor pendukung dan penghambatnya. 3) tentukan langkah-langkah kegiatan serta waktu pencapaiannya. 4) tentukan bagaimana cara mencapainya, dan 5) tentukan tolak ukur menilaikeberhasilannya.

\section{Pengembangan Karakter Anak Usia Dini}

Mulyasa (2012) berpendapat bahwa pendidikan karakter bagi anak usia dini mempunyai makna yang lebih tinggi dari pendidikan moral karena tidak hanya berkaitan dengan masalah benar-salah ,tetapi bagaimana menanamkan kebiasaan (habit) tentang berbagai perilaku yang baik dalam kehidupan sehingga anak memiliki kesadaran dan komitmen untuk menerapkan kebajikan dalam kehidupn sehari-hari. Seorang anak yang sejak kecil dikenalkan dan ditanamkan pendidikan karakter ,diharapkan ketika dewasa karakterkarakter yang diperolehnya akan menjadi kebiasaan bagi dirinya.Oleh karena itu ,peran aktif orang tua, pendidik serta masyarakat untuk bersama-sama menggalakkan nilai-nilai pendidikan karakter dalam setiap kesempatan, khususnya kepada anak-anak usia dini baik di dalam keluarga maupun masyarakat yang ada di lingkungannya .

Perlunya menanamkan nilai-nilai pendidikan karakter untuk mempersiapkan mereka kelak sebagai manusia-manusia yang mempunyai identitas diri, sekaligus menuntun anak untuk menjadi manusia berbudi pekerti, melalui pembiasaan dan keteladanan. Pada pembiasaan adalah suatu cara yang dapat dilakukan untuk membiasakan anak berpikir,bersikap,bertindak sesuai dengan ajaran agama. Pembinaan dan pembentukan karakter anak usia dini dalam meningkatkan pembiasaan-pembiasaan dalam melaksanakan suatu kegiatan disekolah. Pembiasaan adalah pengulangan.Dalam pembiasaan sangat efektif digunakan karena akan melatih kebiasaankebiasaan yang baik kepada anak usia dini. Sebagai contoh,apabila guru setiap masuk kelas mengucapkan salam, itu sudah dapat diartikan 
sebagai usaha pembiasaan. Bila mana ada anak masuk kelas tidak mengucapkan salam,guru sebaiknya mengingatkan anak agar bila masuk ruangan mengucapkan salam. Ini juga salah satu cara membiasakan anak sejak dini.

Peran guru sangat berat dalam era globalisasi , penuh tantangan yang tidak mudah dianggap enteng dalam memaknainya guru dituntut untuk profesional. Oleh karena itu,peran guru dalam menghadapi tantangan globalisasi perlu mengedepankan profesionalisme menurut Kunandar dalam Barnawi \& M.Arifin (2012), ada lima tantangan globalisasi antara lain: 1. Perkembangan IPTEK yang begitu cepat dan mendasar 2 . Krisis moral yang melanda bangsa dan negara Indonesia 3. Krisis sosial seperti kriminalitas, kekarasan,pengangguran, kemiskinan yang melanda masyarakat 4. Krisis identitas bangsa dan negara Indonesia 5. Adanya perdagangan bebas baik ASEAN, Asia Pasifik, dan Dunia.

Peran guru menurut Lickona, Schaps, dan Lewis serta Azra (dalam Suyanto, 2010) adalah sebagai berikut: 1. Dalam upaya membangun karakter pendidik perlu terlibat langsung dalam proses pembelajaran ,berdiskusi,mengambil inisiatif 2. Pendidik bertanggung jawab menjadi model yang memiliki nilai-nilai moral dan memamfatkan kesempatan untuk mempengaruhi siswasiswanya. 3. Pendidik memberikan pengarahan bahwa karakter siswa tumbuh melalui kerjasama dan berpartisipasi dalam mengambil keputusan 4. Pendidik perlu malakukan refleksi atas masalah moral berupa pertanyaan rotin untuk memastikan adanya perkembangan karakter pada siswanya. 5. Pendidik perlu menjelaskan dan mengklarifikasikan kepada peserta didik secara berkesinambungan tentang berbagai nilai yang baik dan yang buruk.

\section{SIMPULAN}

Pendidikan yang utama dan pertama didapat anak dari orang tua. Orang tua memiliki peran penting dalam hal ini sebab orang tua adalah teladan pertama yang dikenal oleh anak. Peran orangtua yang demokratis menerapkan orang tua yang menjadikan anak-anak menjadi orang yang mau menerima kritik dan menghargai orang lain, memiliki kepercayaan diri yang tinggi dan mampu bertanggung jawab atas kehidupan sosial mereka. metode yang diterapkan orang tua dalam penggembangan potensi diri dan karakter anak antara lain: a) memberikan pujian dan penghargaan kepada anak, b) menyediakan waktu bermain bersama anak, c) memberikan kasih sayang dan perhatian, d) memberikan keteladanan yang baik.

\section{DAFTAR RUJUKAN}

Ahmad, Khursid. 1986. Family Life in Islam, diterjemahkan oleh Soetomo dengan judul Keluarga Muslim. Cet. I. Bandung: Risalah.

A.N.Ubaedy. 2005. Menggali Potensi Diri. Jakarta:Restu Agung Beck, Joan. 1992. Asih, Asah, Asuh, Mengasuhdan Mendidik Anak agar Cerdas. Semarang: Dahara.

Corey, Gerald. 2004. Theory and Practice of Counseling and Psychotherapy. Monterey, California : Brooks/Cole Publishing Company. 
.2013. Teori dan praktik konseling dan psikoterapi. Bandung: Aditama.

Depdikbud. 2001. Kamus Besar Bahasa Indonesia Jakarta : Balai Pustaka.

Daradjat, Zakiyah, dkk. 1995. Metodik Khusus Pengajaran Agama Islam. Jakarta: Bumi aksara.

Depdikbud, 2001. Kamus Besar Bahasa Indonesia. Jakarta: Balai Pustaka.

Habsari, Sri. 2005. Bimbingan dan Konseling SMA kelas XI. Jakarta: Grasindo.

Hadi, Sutrisno. 1992. Metode Reseach. Yogyakarta: Andi Offset.

Hauck, Paul. 1993. Psikologi Populer (Mendidik Anak dengan Berhasil) Jakarta: Arcan.

Herbeng Masni. 2017. Peran Pola Asuh Demokratis Orangtua Terhadap Pengembangan Potensi Diri Dan Kreativitas Siswa. Jurnal Ilmiah Dikdaya 6 (1), 58-74

Hurlock,B. Elizabeth. 2000 Perkembangan Anak/Child Development. Jakarta: Erlangga.

Hajarudin, Muhammad. 2009. Makalah Pengantar Ilmu Pendidikan. Http:// Lingkungan Keluarga Dokumen.htm. diakses Senin 04 Januari2016.

Kartini, Kartono. 1992. Peran Keluarga Memandu Anak. Jakarta: Rajawali Press.

Mulyasa .(2012). Manajemen PAUD .Bandung : Remaja Rosdakarya

Munandar, S.C.U. 1999. Kreativitas dan Keberbakatan, Strategi Mewujudkan Bakat Kreatif. Jakarta: Gramedia.

Suharnan. (2002). Skala C.O.R.E sebagai alternatif mengukur kreativitas: suatu pendekatan kepribadian. Anima Indonesian Psychological Journal,18,36.
Munandar, 1998. Hubungan Isteri, Suami dan Anak dalam Keluarga. Jakarta: Pustaka Antara.

Malcom Hardy dan Steve Heyes, Terj. Soenardji. $1986 . \quad$ Pengantar Psikologi. Jakarta: Erlangga.

Muhibbin Syah. 1999. Psikologi Belajar. Jakarta: Logos Wacana Ilmu.

Moleong, Lexy J. 2005 Metodologi Penelitian Kualitatif. Bandung: Remaja Rosda Karya. 